\section{Adjuvants Affect Penetration of Copper Through Isolated Cuticles of Citrus Leaves and Fruit}

\author{
Vladimir Orbović ${ }^{1}$, Diann Achor, and James P. Syvertsen \\ Department of Horticultural Sciences, Citrus Research and Education \\ Center, University of Florida, IFAS, 700 Experiment Station Road, \\ Lake Alfred, FL 33850
}

Additional index words. grapefruit leaves, Silwet L-77, spray-oil, urea, Valencia oranges

\begin{abstract}
Copper (Cu)-based fungicidal sprays are widely used on many crops although $\mathrm{Cu}$ sprays can be phytotoxic under some conditions. The mechanism of phytotoxicity is poorly understood but must involve toxic levels of $\mathrm{Cu}$ penetrating plant tissues. We studied the effect of different adjuvants on the deposition pattern of droplets and penetration of $\mathrm{Cu}$ (in Kocide fungicide) through isolated cuticles of 'Marsh' grapefruit leaves and 'Valencia' orange fruit. The addition of the silicone-based L-77 surfactant to the Kocide suspension markedly increased the spread of the droplets on cuticles and increased the penetration of $\mathrm{Cu}$ through fruit and abaxial leaf cuticles, both with stomatal pores, but not through astomatous adaxial leaf cuticles, which had much lower permeability. Urea and petroleum spray oil adjuvants had no effect on surface area of droplets or the penetration of $\mathrm{Cu}$ through leaf and fruit cuticles. Spray tank mixes of $\mathrm{Cu}$ fungicides with organosilicone surfactants should be avoided because these surfactants can enhance the penetration of $\mathrm{Cu}$ into citrus leaves and fruit thereby leading to phytotoxicity.
\end{abstract}

Copper $(\mathrm{Cu})$ is an important component of the fungicide programs that are used for control of many important diseases of citrus. Copper-based fungicides, used either alone or with spray oil, can successfully control greasy spot, melanose, citrus scab, Alternaria brown spot, and Phytophthora rot and citrus canker (Rogers and Timmer, 2006). The bacterial canker eradication program in Florida was ended in 2005 resulting in the frequent use of multiple applications of $\mathrm{Cu}$ fungicide sprays per year. Despite significant antifungal and antibacterial effects of $\mathrm{Cu}$ on different crops (Reil et al., 1974; Teviotdale et al., 1997), its use has been occasionally problematic because of phytotoxic effects often attributed to inappropriate adjuvants added to spray tank mixes or hypersensitivity of some plant tissues. Incidence of russeting on Granny Smith apples increased when the $\mathrm{Cu}$-based fungicide, Kocide, was applied in late stages of flower and fruit development (Teviotdale et al., 1997). Kocide sprays also increased the percentage of russeted pear fruit across a range of application rates (Reil et al., 1974). Citrus fruit injuries induced by foliar application of $\mathrm{Cu}$-based fungicides deserve study because of their economic impact (Timmer, 1998). Because most $\mathrm{Cu}$ damage occurs on the outside of the fruit on

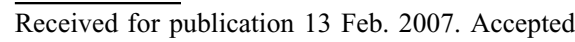
for publication 17 June 2007.

This research was funded in part by the FCPRAC. We acknowledge the help from Deborah van Clief in ICP analysis.

${ }^{1}$ To whom reprint requests should be addressed; e-mail orbovic@ufl.edu. the outer canopy (L.W. Timmer, personal communication), high sprayer pressures may enhance phytotoxic $\mathrm{Cu}$ effects. When sprayed on citrus trees, cuprous oxide can accentuate blemishes and create stipple marks on fruit, thereby decreasing their market value (Brodrick, 1970). Tank mixes that include $\mathrm{Cu}$ can cause blotching of Citrus fruit, and this hazard is greater if oil is included in the mixture (Albrigo et al., 1997). Interactions between $\mathrm{Cu}$ fungicides and other components in spray tank mixes that lead to phytotoxicity are poorly understood, but the low $\mathrm{pH}$ of some spray mixes make $\mathrm{Cu}^{++}$ion much more soluble and increases risk of phytotoxicity.

Fungicidal $\mathrm{Cu}$ deposits are intended to remain on plant surfaces to prevent the invasion and growth of surface pathogens. The mechanism of $\mathrm{Cu}$-induced injuries on fruit and leaves probably involves toxic levels of $\mathrm{Cu}$ penetrating plant tissues. Copper concentration increased in flowers of apple trees following sprays of Kocide + zinc sulfate before flowering (Peryea, 2000) implying that $\mathrm{Cu}$ can penetrate plant tissues. The plant cuticles are the primary barrier through which materials must pass to penetrate tissues (Petracek et al., 1998; Schreiber and Schönherr, 1990). Thus, the dynamics of cuticular penetration can yield insights into foliar uptake (Orbović et al., 2001a) or uptake into the fruit tissue.

The organosilicone surfactant, L-77, has a high surface activity, which results in reduced surface tension of solutions and, in some cases, increased penetration through open stomata (Field et al., 1992). Singh and Singh (1995) described the ability of L-77 to decrease contact angles of droplets of solution leading to enhancement of spreading over leaf surfaces. L-77 improved the efficiency of gibberellin in prolonging the Citrus harvest season (Greenberg et al., 1987). Although $\mathrm{Cu}$ fungicides are not routinely mixed with silicone surfactants or urea in spray tank mixes, the behavior of $\mathrm{Cu}$ fungicides with and without such adjuvants could lead to insights about potential mechanisms of $\mathrm{Cu}$ phytotoxicity.

In this work, we determined the amounts of $\mathrm{Cu}$ that penetrated through cuticles of Citrus leaves and fruit after application of the $\mathrm{Cu}$-based fungicide Kocide with and without L-77, oil, and urea adjuvants. We tested the hypothesis that additions of these adjuvants, silicone L-77, oil, and urea would enhance the potentially toxic penetration of $\mathrm{Cu}$ through citrus plant cuticles.

\section{Materials and Methods}

Cuticle isolation. Healthy appearing 6-month-old (mature) leaves from 15-year-old 'Marsh' grapefruit (Citrus paradisi Macf.) trees and mature fruit from 'Valencia' orange [Citrus sinensis (L.) Osbeck] trees were used as a source of cuticles in this study. Leaf disks of $2.2 \mathrm{~cm}^{2}$ were removed with a sharp cork borer from the midlamina area of leaves avoiding major veins, and from fruit rind, $8.5-\mathrm{cm}^{2}$ disks were removed from the equatorial region. Cuticles were isolated from leaf and fruit disk tissues by digestion in a pectinase $(4 \% \mathrm{w} / \mathrm{v})+$ cellulase $(0.4 \% \mathrm{w} / \mathrm{v})$ solution, which contained Na-citrate buffer (50 mM) adjusted to $\mathrm{pH} 4$ (Yamada et al., 1964). To prevent the growth of microorganisms, $1 \mathrm{~mm}$ of sodium azide was included in the solution. Leaf and fruit disks were incubated for $4 \mathrm{~d}$ at room temperature and were exposed intermittently to a vacuum to facilitate infiltration of digestive enzymes into the tissue. Cuticles were separated from tissue residue under gently flowing water. Any cellular debris remaining on cuticles was redigested overnight in fresh enzymatic solution and cuticles were rinsed again for 2 to $4 \mathrm{~h}$ in running distilled water. Intact cuticles were floated onto a piece of Teflon and left to air-dry before being used in experiments. Adaxial leaf cuticles were selected under the microscope for their lack of stomata and tested for leaks by using a low hydrostatic pressure (Petracek et al., 1998).

Chemicals and adjuvants. The fungicide/ bactericide Kocide DF (Griffin Corp., Valdosta, GA) is a metallic powder that contains $60 \%$ of $\mathrm{Cu}(\mathrm{OH})_{2}(\mathrm{w} / \mathrm{w})$ and $40 \%$ metallic $\mathrm{Cu}$. On average, Kocide particle size is between $2 \mu \mathrm{m}$ and $3 \mu \mathrm{m}$ in diameter. The concentration of Kocide in all preparations was $9.6 \mathrm{~g} / \mathrm{L}$, which corresponds to the recommended rate of field application of $9.6 \mathrm{~kg} \mathrm{Cu}$ fungicide per ha in $1000 \mathrm{~L}$ of spray volume. Five suspensions of Kocide were tested. As an adjuvant (a weak nonionic penetrant), urea (Fischer Chemical, Fair Lawn, NJ) was added to Kocide at a concentration of $1.65 \%(\mathrm{w} / \mathrm{v})$. The concentration of urea was equivalent to 
$7.74 \mathrm{~kg} \cdot \mathrm{ha}^{-1}$. The organosilicone surfactant and penetrant Silwet L-77, a polyalkeneoxide copolymer (Loveland Industries, Greenley, CO), was added at a concentration of $0.15 \%(\mathrm{v} / \mathrm{v})$ to make the Kocide + L-77 preparation. Agricultural petroleum spray oil Sunspray $7 \mathrm{~N}\left(224{ }^{\circ} \mathrm{C}-50 \%\right.$ distillation temperature; Sun Refining and Marketing Co., Philadelphia, PA) was added to Kocide at $8 \mathrm{~mL} \cdot \mathrm{L}$, which corresponds to $0.15 \%(\mathrm{v} / \mathrm{v})$ and rate of field application of $9.25 \mathrm{~L} \cdot \mathrm{ha}$. Spray oil is a spreader and sticker type of nonionic adjuvant. An additional combination of Kocide + urea + oil was tested by mixing the three materials as described previously. Preparations of Kocide alone, Kocide with urea, Kocide with oil, and Kocide with urea + oil had a $\mathrm{pH}$ of 9.93 to 9.95 , whereas Kocide + L-77 had a $\mathrm{pH}$ of 7.80. $\mathrm{pH}$ measurements were done with a $\mathrm{pH}$ meter (Orion 290A; Orion Research, Boston) on freshly prepared solutions.

Measurement of cuticular penetration. In vitro measurements of cuticular penetration of $\mathrm{Cu}$ were done as previously described by Petracek et al. (1998) with only slight modifications. Isolated cuticles were mounted with their outer surface up in a $2.8-\mathrm{cm}$ diameter $\left(6.2 \mathrm{~cm}^{2}\right)$ Plexiglas ring holder with an 8-mm o-ring opening above a $4-\mathrm{mL}$ reservoir bowl. The subtending reservoir was filled with well-stirred deionized water that was in full contact with the inner cuticle surface. At time zero, three $2-\mu \mathrm{L}$ droplets of the different Kocide preparations (containing $\approx 23 \mu \mathrm{g}$ of $\mathrm{Cu}$ total) were deposited onto the cuticle. After $24 \mathrm{~h}$, the ring holder with the cuticle was detached from the experimental cell and the content of the reservoir poured into a plastic tube. The penetration of $\mathrm{Cu}$ through leaf abaxial and fruit cuticles with stomata was rapid and, as a result, the amount of $\mathrm{Cu}$ detected in the reservoir $1 \mathrm{~h}$ after deposition of droplets did not increase significantly (data not shown). The liquid in the reservoir was analyzed for the concentration of $\mathrm{Cu}$ that passed through the cuticle using inductively coupled plasma emission spectroscopy (Plasma 40 instrument; PerkinElmer Corp., Norwalk, CT). All penetration experiments were done under laboratory conditions of air temperature $\left(23 \pm 2{ }^{\circ} \mathrm{C}\right)$ and humidity at $35 \%$ to $50 \%$. Each experiment was repeated at least five times with two to four replicate cuticles for a total of 10 to 20 replicate cuticles tested for each treatment resulting in 15 batches of data. Collected data were analyzed for variability with Duncan multiple range test at $P<0.05$. For each type of cuticle, the batch of data representing penetration of one $\mathrm{Cu}$ preparation was compared with penetration data obtained with four other $\mathrm{Cu}$ preparations. The second comparison was done to separate the mean values for penetration of each $\mathrm{Cu}$ preparation through different type of cuticles.

Measurement of droplet surface area. One-microliter droplets of different preparations of Kocide with and without adjuvants were deposited on both abaxial and adaxial side of fresh intact leaves and fruit peels, observed using a video camera, and allowed to spread for $60 \mathrm{~s}$. After this period, a digital image of the droplets' surface area was captured and analyzed using Image-Pro Plus image analysis software (Media Cybernetics, Silver Spring, MD). The number of measurements for each treatment on all three surfaces was 12 to 35 and data were grouped in 15 batches. Collected data were analyzed for variability with Duncan multiple range test at $P<0.05$. For each type of surface, the batch of data representing droplet spreading for one $\mathrm{Cu}$ preparation was compared with spreading data obtained with four other $\mathrm{Cu}$ preparations. The second comparison was done to separate the mean values for droplet spreading of each $\mathrm{Cu}$ preparation applied to different surfaces.

Transmission electron microscopy. Small samples of mature grapefruit peel were fixed for $4 \mathrm{~h}$ at room temperature with 3\% glutaraldehyde in $0.1 \mathrm{M}$ potassium phosphate buffer $\mathrm{pH}$ 7.2. They were then washed in the same buffer and postfixed in $2 \%$ osmium tetroxide in $0.1 \mathrm{M}$ potassium phosphate buffer $\mathrm{pH} 7.2$ for $4 \mathrm{~h}$ at room temperature. The samples were then washed three times in buffer, dehydrated in acetone, and embedded in Spurr's plastic (Spurr, 1969). One-micron sections were made for the light microscope, stained in methylene blue/azure A and basic fuchsin (Schneider, 1981), then searched for mature stomata in the cross-section. When located, the area of the epidermis locating them was trimmed and $100-\mathrm{nm}$ sections were made with a diamond knife mounted on 200 mesh formvar-coated grids and stained with $2 \%$ aqueous uranyl acetate and lead citrate (Reynolds, 1963). The grids were examined with a Morgagni transmission electron microscope (FEI Company, Hillsboro, OR) and photographed with an AMT digital camera (Advanced Microscopy Techniques Corp., Danvers, MA).

\section{Results}

The surface area covered by $1-\mu \mathrm{L}$ droplets of Kocide alone (without adjuvants) deposited on either the adaxial and abaxial surface of fresh grapefruit leaves or on fresh mature orange fruit peels was $\approx 2 \mathrm{~mm}^{2}$ (Fig. 1). Addition of urea and spray oil either alone or together to Kocide slightly increased surface area of droplets on both sides of the leaf to between 2.5 and $3 \mathrm{~mm}^{2}$. These two adjuvants had no effect on surface area of droplets deposited on fruit rind because their surface area remained $\approx 2 \mathrm{~mm}^{2}$. In contrast, the wetting agent L-77 had a pronounced effect on the surface area of droplets on all three surfaces tested. The surface area of the Kocide + L-77 droplet was $\approx 19 \mathrm{~mm}^{2}$ when deposited on the abaxial side of leaves, more than $51 \mathrm{~mm}^{2}$ on fruit rind, and $131 \mathrm{~mm}^{2}$ on adaxial side of leaves (Fig. 1).

Penetration of $\mathrm{Cu}$ from different preparations of Kocide through fruit and abaxial leaf cuticles within $1 \mathrm{~h}$ after the application of fungicide (Fig. 2) exhibited similar trends to that of droplet spreading on abaxial side of leaves. The highest total amounts of $\mathrm{Cu}$ $(\approx 1.1 \mu \mathrm{g})$ penetrated through both fruit and abaxial leaf cuticles (both with stomata) after application of Kocide + L-77. When Kocide was applied alone, in combination with urea or with petroleum oil, or in the combined oil + urea preparation, the amount of $\mathrm{Cu}$ that penetrated fruit and abaxial cuticles was between $0.05 \mu \mathrm{g}$ and $0.18 \mu \mathrm{g}$. Twenty-four hours after application of Kocide to adaxial leaf cuticles, only $\approx 0.045 \mu \mathrm{g}$ of $\mathrm{Cu}$ passed through these relatively dense, astomatous cuticles regardless of the presence or absence of adjuvants.

The weight per unit area, an estimate of cuticle thickness, of cuticles isolated from the abaxial side of grapefruit leaves as well as from the equatorial plane of fruit was lower than that of cuticles isolated from adaxial side of leaves (Table 1). The cuticles of cells in the substomatal cavity appeared thinner than the cuticles of epidermal cells of a grapefruit rind (Fig. 3).

\section{Discussion}

The addition of petroleum spray oil and urea either alone or mixed together did not change the basic $\mathrm{pH}$ of 9.9 of the Kocide suspensions. Most heavy metal ions readily precipitate at high $\mathrm{pH}$ by forming the respective metal hydroxide compound (Gaydardjiev et al., 1996; for the example of titration measurements, see www.hoffland.net/src/tks/ 3.xml). An increase of two $\mathrm{pH}$ units can result in a 40-fold decrease in solubility of $\mathrm{Cu}$. At $\mathrm{pH}$ of $9.9, \mathrm{Cu}$ solubility would be low, leaving a low concentration of free $\mathrm{Cu}$ ions. On the other hand, the lower $\mathrm{pH}$ (7.8) of the L-77 + Kocide solution undoubtedly increased the solubility of $\mathrm{Cu}$ above that at pH 9.9 .

In previous field studies, the addition of petroleum spray oil at $9.3 \mathrm{~L} \cdot$ ha to a Kocide spray tank mixture to be applied at $4.5 \mathrm{~kg} \cdot \mathrm{ha}$ of $\mathrm{Cu}$ produced a small amount of grapefruit rind burn (Albrigo et al., 1997). This phytotoxic effect of oil with $\mathrm{Cu}$ declined with dilution when the spray volume increased from $235 \mathrm{~L} \cdot$ ha to $1168 \mathrm{~L} \cdot \mathrm{ha}$. However, combining $46.5 \mathrm{~L} \cdot \mathrm{ha}$ of oil with Kocide DF resulted in a severe burn of the outer surface of exposed fruit (Albrigo et al., 1997). In addition, spray oil with $\mathrm{Cu}$ hydroxide enhanced blemishes of fruit and darkening of the damaged areas on lemons (Rae et al., 1996). In our experiments, the addition of oil had little effect on the surface area of droplets of Kocide deposited on the three types of cuticles (Fig. 1). The amount of $\mathrm{Cu}$ that penetrated through cuticles also was not changed with the addition of spray oil (Fig. 2). We used the oil rate of $9.26 \mathrm{~L} \cdot$ ha in the spray volume of $469 \mathrm{~L}$, which falls within the range of 235 to $1168 \mathrm{~L}$ in which the negative effect of oil was reported to decrease with spray volume (Albrigo et al., 1997). Thus, penetration would not be great enough to result in phytotoxicity. In addition, there is also a possibility that the reported $\mathrm{Cu}$ injury after application of Kocide + oil may not have 


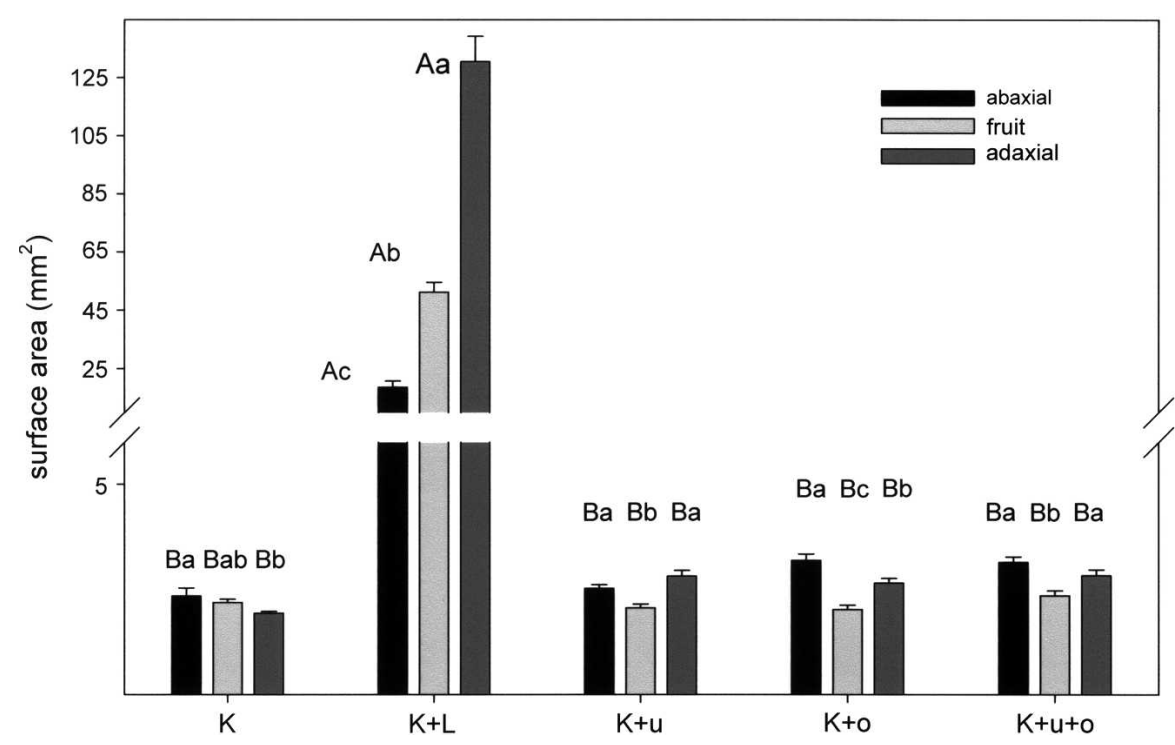

Fig. 1. The effect of different adjuvants on surface area of droplets of Kocide deposited on abaxial and adaxial surfaces of grapefruit leaves and the exterior surface of orange fruit rind. $\mathrm{K}=$ Kocide; $\mathrm{K}+\mathrm{L}=$ Kocide + L-77; $\mathrm{K}+\mathrm{u}=$ Kocide + urea; $\mathrm{K}+\mathrm{o}=$ Kocide + oil $; \mathrm{K}+\mathrm{u}+\mathrm{o}=$ Kocide + urea + oil. Concentrations of chemicals used: K- $0.96 \%$ (w/v), u- $1.65 \%$ (w/v), L- $0.15 \%(\mathrm{v} / \mathrm{v}), \mathrm{o}-0.15 \%(\mathrm{v} / \mathrm{v})$. Bars represent means $\pm \mathrm{SE} ; \mathrm{n}=23-25$. Means followed by different letters differ significantly as tested with Duncan's multiple range test at $P<0.05$; upper case letters separate means calculated for different copper preparations; lower case letters separate means calculated for different type of surfaces.

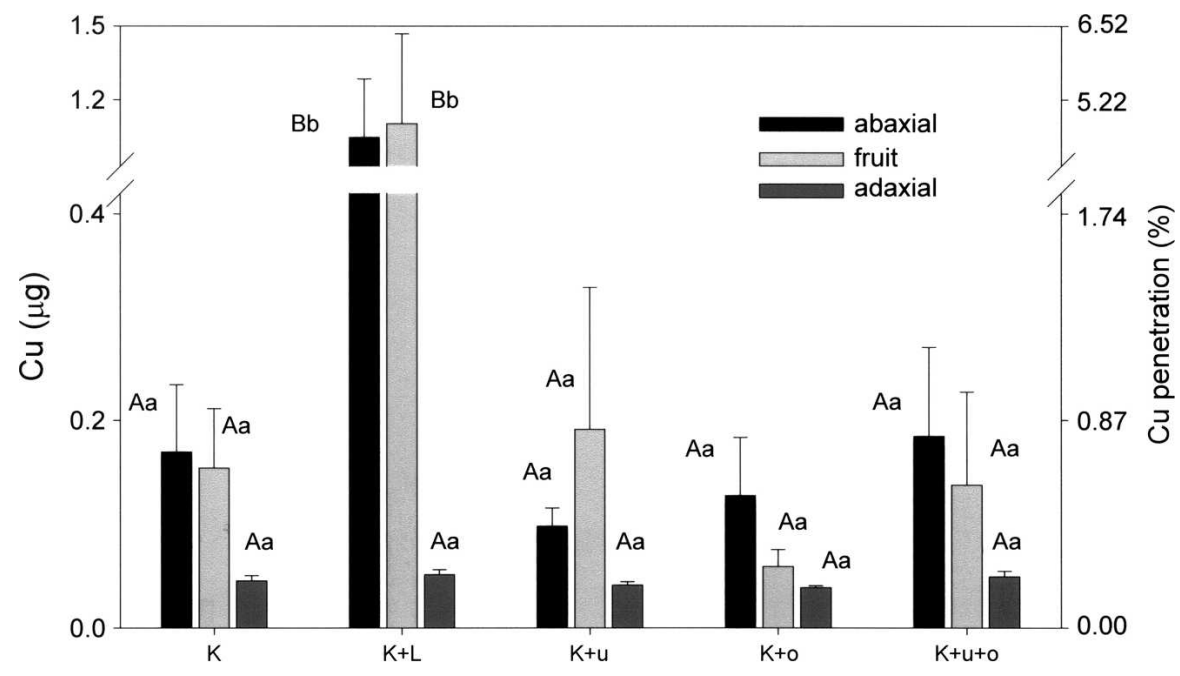

Fig. 2. The effect of different adjuvants on penetration of copper $(\mathrm{Cu})$ through isolated abaxial and adaxial leaf cuticles and fruit cuticles. $\mathrm{K}=$ Kocide; $\mathrm{K}+\mathrm{L}=$ Kocide $+\mathrm{L}-77 ; \mathrm{K}+\mathrm{u}=$ Kocide + urea; $\mathrm{K}+\mathrm{o}=$ Kocide + oil $; \mathrm{K}+\mathrm{u}+\mathrm{o}=$ Kocide + urea + oil. Concentrations of chemicals used: $\mathrm{K}-0.96 \%(\mathrm{w} / \mathrm{v})$, $\mathrm{u}-1.65 \%(\mathrm{w} / \mathrm{v}), \mathrm{L}-0.15 \%(\mathrm{v} / \mathrm{v}), \mathrm{o}-0.15 \%(\mathrm{v} / \mathrm{v})$. Bars represent means $\pm \mathrm{SE} ; \mathrm{n}=12-35$. Means followed by different letters differ significantly as tested with Duncan's multiple range test at $P<0.05$; upper case letters separate means calculated for different $\mathrm{Cu}$ preparations; lower case letters separate means calculated for different type of cuticles.

Table 1. The weight per area of cuticles isolated from abaxial and adaxial side of grapefruit leaves and from the equatorial plane of Valencia orange fruit.

\begin{tabular}{lccc}
\hline & \multicolumn{3}{c}{ Cuticle source } \\
\cline { 2 - 4 } & Adaxial $(\mathrm{n}=15)$ & Abaxial $(\mathrm{n}=26)$ & Fruit $(\mathrm{n}=22)$ \\
\hline Cuticle weight $\left(\mathrm{g} / \mathrm{m}^{2}\right)$ & $6.66+0.85 \mathrm{a}^{\mathrm{z}}$ & $5.50+0.24 \mathrm{~b}$ & $5.04+0.29 \mathrm{~b}$ \\
\hline
\end{tabular}

${ }^{2}$ Means followed by different letters differ significantly as tested with Duncan's multiple range test at $P<0.05$.

been the consequence of passage of $\mathrm{Cu}$ through the cuticle itself but rather through stomatal pores in the cuticle. The relatively few stomata in mature fruit cuticles are not as

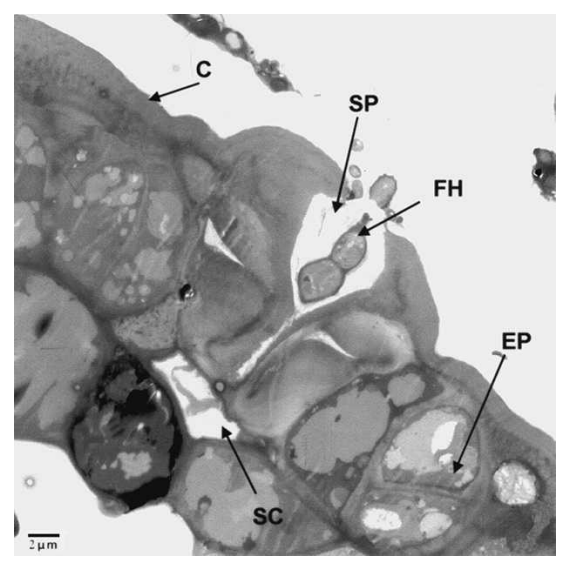

Fig. 3. Transmission electron micrograph of stomata of mature grapefruit peel in cross-sectional view showing cuticle $(\mathrm{C})$, epidermal cells (EP), stomatal pore (SP), substomatal cavity (SC), and fungal hyphae (FH).

substomatal chambers where mesophyll cell walls are not protected with a thick cuticle (Fig. 3). Plant cell walls are known to be acidic environments (Brett and Waldron, 1996), so once $\mathrm{Cu}$ particles come into contact with cell walls, $\mathrm{Cu}$ ions could become more soluble at the lower $\mathrm{pH}$. Consequently, higher levels of free $\mathrm{Cu}$ ions could penetrate the cell walls resulting in increased phytotoxicity.

The addition of urea to the Kocide suspension had no effect on the surface area of droplets deposited on either side of grapefruit leaves or on the surface of orange fruit (Fig. 1). Urea also had no effect on the penetration of $\mathrm{Cu}$ through any of the tested cuticles (Fig. 2). Absorption of some foliarapplied nutrients was enhanced by previous urea sprays (Bowman and Paul, 1992), but this effect was apparently not attributable to the ability of urea to facilitate spreading (Fig. 1). Although urea can be acidic in solution, urea had no effect on the $\mathrm{pH}$ of the Kocide suspension at the concentration used here. Thus, $\mathrm{pH}$ of the Kocide + urea suspension did not affect $\mathrm{Cu}$ solubility or $\mathrm{Cu}$ penetration.

The action of organosilicone surfactants such as L-77 has been attributed to their ability to increase the spread of droplets by lowering surface tension (Schönherr and Bukovac, 1972).

L-77 by itself is a relatively safe chemical for foliar sprays because only minor negative effects on citrus photosynthesis were reported when L-77 was applied alone or in combination with urea (Orbović et al., 2001b). Addition of L-77 to the Kocide suspension reduced the $\mathrm{pH}$ from 9.9 to 7.8 , increased the surface area of droplets deposited on cuticles (Fig. 1), and produced a fivefold increase in the amount of $\mathrm{Cu}$ that penetrated through abaxial leaf and fruit cuticles with stomata (Fig. 2). There are three possible explanations for the increase in penetration. First, L-77 increased the surface area covered and number of stomata contacted by Kocide resulting in higher direct penetration of $\mathrm{Cu}$. Second, the decrease in $\mathrm{pH}$ resulting from the addition of L-77 created an environment favorable for an increase of the concentration of free $\mathrm{Cu}$ ions 
that could move through stomata. Third, L-77 is known to selectively dissolve certain cuticular waxes, which may affect the penetration of compounds sprayed on the leaves or fruits (Greenberg et al., 1987).

The increase in the surface area of Kocide + L-77 droplets deposited on the relatively thick adaxial leaf cuticles, however, did not result in any increase in the amount of $\mathrm{Cu}$ penetration within the first hour (Fig. 2). In time course studies using a small subsample of cuticles, there was no change in penetration of copper through cuticles between 1 and $24 \mathrm{~h}$ (data not shown). The exposed cuticle surface area in the Plexiglas holder was $50 \mathrm{~mm}^{2}$, much smaller than the surface area of Kocide + L-77 droplets (Fig. 1), so the full effect of L-77 may not have been realized.

A concentration of $\mathrm{Cu}$ in citrus leaves of $20 \mu \mathrm{g} \cdot \mathrm{g}^{-1}$ of dry weight is considered excessive and can decrease yields of citrus trees (Tucker et al., 1995). When three 2- $\mu \mathrm{L}$ droplets of Kocide + L-77 were deposited on cuticles, droplets completely covered the $50 \mathrm{~mm}^{2}$ of available surface area of the cuticles mounted between two pieces of Plexiglas holder. The amount of $\mathrm{Cu}$ that penetrated abaxial and fruit cuticles was $\approx 1 \mu \mathrm{g}$ (Fig. 2), which means that $\approx 2 \mu \mathrm{g}$ penetrated per $1 \mathrm{~cm}^{2}\left(1 \mu \mathrm{g} / 0.5 \mathrm{~cm}^{2}\right)$. Because $1 \mathrm{~g}$ of dry weight of citrus leaves corresponds to a surface area of $\approx 100 \mathrm{~cm}^{2}$, it follows that the amount of $\mathrm{Cu}$ that would have gotten into the leaves could be as high as $200 \mu \mathrm{g}(100 \times$ $2 \mu \mathrm{g}$ ). By this estimation, citrus leaves would contain $\approx 10$ times the toxic levels of $\mathrm{Cu}$ after the spraying of Kocide formulated with L-77 if the spray coverage was $100 \%$. Using more reasonable spray coverage on target leaves of $\approx 50 \%$ (Salyani and Fox, 1999), however, penetration would still be more than five times the toxic levels for citrus leaves. Although toxic concentrations have not been established for $\mathrm{Cu}$ in citrus fruit, amounts found in fruit after spaying with the Kocide + L-77 combination also would probably be in a phytotoxic range. Stipple marks on lemons were the direct result of injury by $\mathrm{Cu}$, whereas blemishes were accentuated by $\mathrm{Cu}$ coverage (Brodrick, 1970). Adjuvants such as sodium carbonate, and especially slaked lime, significantly decreased the damaging effects of $\mathrm{Cu}$ (Brodrick, 1970), perhaps because both sodium carbonate and slaked lime increased the $\mathrm{pH}$ of spray suspensions causing $\mathrm{Cu}$ to precipitate from solution
(Parker, 1981), thereby leaving less $\mathrm{Cu}$ in solution available for penetration.

In conclusion, because $\mathrm{Cu}$ ions can penetrate directly through cuticles and stomata, care should be taken when mixing different chemicals with $\mathrm{Cu}$-based fungicides for spraying citrus. Tank mixes of organosilicone surfactants with $\mathrm{Cu}$ should be avoided because they will undoubtedly enhance penetration of $\mathrm{Cu}$ into leaves and fruit by decreasing the $\mathrm{pH}$ of Kocide and increasing spreadability. Mixing of Kocide with urea and spray oil at the concentrations used here will not increase $\mathrm{Cu}$ penetration as long as the concentration of oil is kept low and spray volumes are high.

\section{Literature Cited}

Albrigo, L.G., L.W. Timmer, K. Townsend, and H.W. Beck. 1997. Copper fungicides-residues for disease control and potential for spray burn. Proc. Fla. State Hort. Soc. 110:67-70.

Bowman, D.C. and J.L. Paul. 1992. Foliar absorption of urea, ammonium, and nitrate by perennial ryegrass turf. J. Amer. Soc. Hort. Sci. 117:75-79.

Brett, C.T. and K.W. Waldron. 1996. Physiology and biochemistry of plant cell walls. Chapman and Hall, London, UK.

Brodrick, H.T. 1970. Accentuation of blemish marks by copper fungicide sprays. S. A. Citrus J. 441:27-30.

Field, R.J., N.C. Dobson, and L.J. Tisdall. 1992. Species-specific sensitivity to organosilicone surfactant-enhancement of glyphosate uptake, p. 424-431. In: C.L. Foy (ed.). Adjuvants for agrichemicals. CRC Press, Boca Raton, FL.

Gaydardjiev, S., M. Hadjihristova, and R. Tichy. 1996. Opportunities for using low-cost methods for metal bearing aqueous streams. Miner. Eng. 9:947-964.

Greenberg, J., S.P. Monselise, and E.E. Goldschmidt. 1987. Improvement of gibberellin efficiency in prolonging the Citrus harvest season by the surfactant L-77. J. Amer. Soc. Hort. Sci. 112:625-629.

Orbović, V., D. Achor, P.D. Petracek, and J.P. Syvertsen. 2001a. Air temperature, humidity and leaf age affect penetration of urea through Citrus leaf cuticles. J. Amer. Soc. Hort. Sci. 126:44-50.

Orbović, V., J.L. Jifon, and J.P. Syvertsen. 2001b. Foliar-applied surfactants and urea temporarily reduce carbon assimilation of grapefruit leaves. J. Amer. Soc. Hort. Sci. 126:625-629.

Parker, A.J. 1981. Introduction: The chemistry of copper, p. 1-22. In: J.F. Loneragan, A.D. Robson, and R.D. Graham (eds.). Copper in soils and plants. Academic Press, Sydney, Australia.

Peryea, F.J. 2000. Recommended prebloom copper spray has no beneficial effect on 'Delicious' apple tree copper status or fruit typeness. J. Plant Nutr. 23:517-528.

Petracek, P.D., R.G. Fader, M. Knoche, and M.J. Bukovac. 1998. Surfactant-enhanced penetration of benzyladenine through isolated tomato fruit cuticular membranes. J. Agr. Food Chem. 46:2346-2352.

Rae, D.J., G.A.C. Beattie, D.M. Watson, Z.M. Liu, and L. Jiang. 1996. Effects of petroleum spray oils without and with copper fungicide on the control of Citrus leafminer, Phyllocnistis citrella Stainton (Lepidoptera: Gracillariidae). Aust. J. Entomol. 34:247-251.

Reil, W.O., S.V. Thomson, M.N. Schroth, W.H. Griggs, and W.J. Moller. 1974. Pear fire blight control tests, 1973. Calif. Agr. 28:4-6.

Reynolds, E.S. 1963. The use of lead citrate at high $\mathrm{pH}$ as an electron-opaque stain in electron microscopy. J. Cell Biol. 17:208-212.

Rogers, M. and L.W. Timmer. 2006. Florida citrus pest management guide. In: M.E. Rogers and L.W. Timmer (eds.). Univ. of Fla., Coop. Ext. Serv., IFAS. SP-43.

Salyani, M. and R.D. Fox. 1999. Evaluation of spray quality by oil- and water-sensitive papers. Trans. ASAE 42:37-43.

Schneider, H. 1981. Plant anatomy and general botany, p. 315-373. In: G. Clark (ed.). Staining procedures for biological stain commission 4th ed. Baltimore, Williams \& Wilkins.

Schönherr, J. and M.J. Bukovac. 1972. Penetration of stomata by liquids, dependence of surface tension, wettability, and stomatal morphology. Plant Physiol. 49:813-819.

Schreiber, L. and J. Schönherr. 1990. Phase transition and thermal expansion coefficients of plant cuticles. Planta 182:186-193.

Singh, M. and D. Singh. 1995. Rainfastness of glyphosate by adjuvants, p. 385-390. Proc. 4th Intl. Symp. on Adjuvants for Agrochemicals.

Spurr, A.R. 1969. A low-viscocity epoxy resin embedding medium for electron microscopy. J. Ultrastruct. Res. 26:31-43.

Syvertsen, J.P. and L.G. Albrigo. 1980. Season and diurnal citrus leaf and fruit water relations. Bot. Gaz. 141:440-446.

Teviotdale, B.L., M. Viveros, and J.A. Grant. 1997. Apple russetting influenced by more than copper sprays. Calif. Agr. 51:11-14.

Timmer, L.W. 1998. The golden rules of copper usage. Fla. Grower 3:20.

Tucker, D.P.H., A.K. Alva, L.K. Jackson, and T.A Wheaton. 1995. Nutrition of Florida citrus trees. University of Florida, Gainesville, FL.

Yamada, Y., S.H. Wittwer, and M.J. Bukovac. 1964. Penetration of ions through isolated cuticles. Plant Physiol. 39:28-32. 